\title{
Teaching Maths within a Transmedia Learning Approach. What Is It and How Sustainable Can It Be?
}

\author{
Anna Sánchez-Caballé ${ }^{1}$ (D) and Juan González-Martínez ${ }^{2, *}$ (D) \\ 1 Facultad de Humanidades y Ciencias Sociales, Universidad Isabel I, 09003 Burgos, Spain; \\ anna.sanchez.caballe@ui1.es \\ 2 Departament de Pedagogia, Facultat d'Educació i Psicologia, Universitat de Girona, 17004 Girona, Spain \\ * Correspondence: juan.gonzalez@udg.edu; Tel.: +34-972-41-83-14
}

Citation: Sánchez-Caballé, A.; González-Martínez, J. Teaching Maths within a Transmedia Learning Approach. What Is It and How Sustainable Can It Be? Sustainability 2021, 13, 13418. https://doi.org/ $10.3390 /$ su132313418

Academic Editors: Pascual D. Diago Nebot and Dionisio F. Yáñez

Received: 30 October 2021

Accepted: 30 November 2021

Published: 3 December 2021

Publisher's Note: MDPI stays neutral with regard to jurisdictional claims in published maps and institutional affiliations.

Copyright: (C) 2021 by the authors. Licensee MDPI, Basel, Switzerland. This article is an open access article distributed under the terms and conditions of the Creative Commons Attribution (CC BY) license (https:/ / creativecommons.org/licenses/by/ $4.0 /)$.

\begin{abstract}
This article addresses the concept of transmedia learning proposed by Jenkins from the perspective of the teaching-learning of mathematics and the sustainability of this type of processes. To this purpose, a scoping review of the literature has been carried out on the Web of Science, Scopus, ERIC, Dialnet and Google Scholar databases. The research process started with a total of 42 scientific documents, and after the corresponding selection process, a total of 14 documents were obtained. From the analysis of the selected documents, it was found that the teaching-learning transmedia learning processes in mathematics tend to be simple and aimed at a very young audience (usually children). Furthermore, most of them are aligned with the United Nations Sustainable Development Goal 4 concept of quality education. However, if sustainability is analysed from a more environmental perspective, none of them make explicit mention of it, although they tend to make responsible use of material resources.
\end{abstract}

Keywords: transmedia; transmedia learning; maths; sustainability

\section{Introduction}

Beyond the general reflection on the impact of technologies on teaching-learning (T-L) processes, in recent years, the literature has focused on everything that has to do with multimedia (both from the didactic perspective and in relation to the necessary literacies required in these approaches) [1,2]. In all this, the success of Jenkins' [3] concept of transmedia is clear in cultural approaches, and it has also landed successfully in the pedagogic context. In this regard, Jenkins [3] says that transmedia storytelling is a "story [that] unfolds across multiple media platforms, with each new text making a distinctive and valuable contribution to the whole. In the ideal form of transmedia storytelling, each medium does what it does best-so that a story might be introduced in a film, expanded through television, novels, and comics; its world might be explored through game play or experienced as an amusement park attraction". However, as is often the case when a term has grown so rapidly, it is difficult to refer to it in a shared and univocal way of understanding of the concept, and therefore, the notion can be used under a general umbrella but from very different ramifications that arise from it (in our case, associated concepts such as transmedia learning (hereafter TL), transmedia literacy and transmedia storytelling, among others).

Nevertheless, when we mention the term transmedia, it is essential to refer to two important ideas of this referential framework, such as media convergence and participatory culture (among other important concepts from Jenkins' ideas). In a first step, we can point out the paradigmatic example of the Matrix and the myriad of cultural productions in the most assorted media and languages, analogue and digital; in that particular coordinates, participatory culture can be perfectly analysed since these productions, commercial or non-commercial, of recognised or collective authorship become part of a varied flow of sequential production and consumption. As a consequence of this, convergence culture 
can be understood as "the flow of content across multiple media platforms, the cooperation between multiple media industries, and the migratory behaviour of media audiences who will go almost anywhere in search of the kinds of entertainment experiences they want. Convergence is a concept that manages to describe technological, industrial, cultural, and social changes depending on who's speaking and what they think they are talking about" [3]. Additionally, from it, we arrive at participatory culture, which contrasts with older notions of passive media spectatorship. Rather than talking about media producers and consumers as occupying separate roles, we might now see them as participants who interact with each other according to a new set of rules that none of us fully understands. Not all participants are created equal. Corporations-and even individuals within corporate media-still exert an increased power than any individual consumer or even the aggregate of consumers. In this sense, some consumers have greater abilities to participate in this emerging culture than others [3]. In all of this, it is important to highlight that the subject goes from consumer to prosumer, with new media literacies that allow one to participate and that catapult them to a central role [4], and this idea has very powerful importance in terms of learning. In fact, according to this, if we change it to the educational field, we begin from constructivist approaches and, under the shadow of connectivism, we can think more about a "do it together" approach than a "do it yourself" one [3,4].

Additionally, we can consider certain ageism in a considerable part of this recent reality. Thus, for instance, on how this new way of consuming and producing lands, for example, the Transmedia Literacy project $[5,6]$, tries to overcome the classic approaches of media education and investigates from an ethnographic perspective the (trans)media practices of young people in the formal and informal spheres, and, through this, it offers a new taxonomy of components of this transmedia literacy. Without any doubt, there are lessons to be learned from this, and it is perhaps one of the gateways to what interests us, which is the relationship between transmedia and education.

\section{Theoretical Framework}

As already highlighted above, not only transmedia has an important echo in general (from a media perspective) but also from an educational perspective. According to that, a couple of years ago, the different approaches that the concept could have in the context of learning were analysed [7]. This study concluded that, in the educational field, transmedia could be understood as a media product, as a cultural phenomenon for which subjects require special literacies or as a new way of understanding the design of teaching-learning experiences. Additionally, it is here that we come again to the initial Jenkins's ideas, and we conclude that participation and production are learning opportunities. This also leads us back again to Scolari in his analysis of the formal and informal media practices of teens.

It is clear that making the leap to participation, as well as to production, allows us to learn. However, what is understood in the literature by transmedia learning? Maybe one of the key ideas to start this analysis is to begin from one of the specific latest reflections on the matter when Dickinson-Delaporte et al. [8] focuses on the difficulties of defining the concept of transmedia in the educational sphere: every text recognises Jenkins' conceptual framework, and the inspiring ideas of media convergence and participatory culture, but there are numerous modes of understanding transmedia in general and in its (conscious and motivated) educational application. As an example of this, these authors highlight the existence of multiple transmedia interpretations (transmedia storytelling, branding, performance, ritual, activism or spectacle), and something similar would happen when we talk about transmedia learning experiences. Because of that, perhaps, we can point out one of the first attempts at conceptualisation, when Fleming [9] laid the foundations for what has been picked up in subsequent literature (only indirectly, since no explicit references can be found to this definition). In this sense, this author says that TL can be understood as:

"the application of storytelling techniques combined with the use of multiple platforms to create an immersive learning landscape which enables multivarious entry and exit points for learning and teaching. It is the unifying concept of the 
learning environment that is important since that can become a landscape for learning that has few, if any, boundaries." [9]

As we said, although this definition has not been adopted by the following theoretical approximations, it allows us to focus on some of the elements that can be highlighted in them: the socio-constructivist approach, the sequential navigation through different media, the leap from the traditional limits (temporal and special) of formal learning and the key role of a narrative [10].

Regarding the learning paradigm, the elements that are pointed out, beyond the socio-constructivist positioning, place the student as the centre [8,11-13] and call for using elements of everyday life that not only make learning more significant (because of their greater transfer potential) but also link more directly to elements of daily life [14], which should have a direct impact in terms of engagement (one of the opportunities commonly suggested when approaching TL) $[15,16]$.

After focusing on this socio-constructivist approach, three elements stand out, according to what we found in the documents consulted: the technological one, the collective dimension (interaction and communication, which leads us to connectivism) and the central role of narrative as a didactic strategy. TL is a direct concretisation of the infinite possibilities derived from both the spectacular technological development and the environment of participatory culture and media convergence; that's evident, and transmedia cannot be understood without that in a general way. In this sense, it is easy to think that TL is a step further in the discourse on digital literacy and that it comes directly from it $[10,17]$. In fact, in the same sense, it transcends the discourse of multimedia insofar as the alternation between the analogue and the digital, as well as the overlap between the different digital ways of expression, which are also natural; with this, it also becomes natural to go beyond the walls of the school institution in the strict meaning $[18,19]$. This alternation is free, with few limits of time, space, order and channels, "if any", as we have seen in Fleming's [9] definition with which we have begun.

Another relevant topic, as can be easily inferred from the general Jenkinsian context from which we started, is the community dimension in which both informal and formal transmedia learning takes place. Here, we have a wide range, ranging from the logical mention of simple interaction to the most complex collaboration, always as essential conditions for learning $[20,21]$. However, beyond the direct search for interaction or collaboration, transmedia learning essentially becomes communitarian, so that it revolves around the construction of learning communities, virtual or face-to-face [22,23] (Campalans, 2015; Rodrigues \& Bidarra, 2015) in such a way that collective intelligence is the main stimulus for learning (Barreneche et al., 2018) and a main agent of dynamisation in T-L processes also in the formal sphere, especially in the design and management of learning ecosystems and environments $[24,25]$. In this way, and also as we saw in the initial definition, the links of TL with connectivism are added to the socioconstructivist roots [14,22] and are embodied in many processes of shared transmediality and transauthorship (Rodrigues \& Bidarra, 2015) or shared assumption of alternative identities in the service of learning [16,25].

Thirdly, as we mentioned above, there is the question of narrative, which is partly what always ends up being linked to a large extent to the field of language learning $[8,16,18,20,26]$. Regardless of whether a didactic objective of this type is pursued, the narrative always accompanies transmedia learning experiences in such a way that, although we cannot always say that it is a storytelling process, it is story-driven learning indeed, even as it is created in step with this narrative (fictional or not), whether we are the ones who formulate it or the ones who let ourselves be carried along by it when we learn. There is overall consensus on the infinite opportunities offered by using narrative as a didactic axis, largely because of its flexibility and malleability because of the engagement achieved [15] or because the possibility that this story has no end (never-ending narratives) generates potentially infinite lines of learning that do not necessarily have an end a priori.

Beyond all this information and elements mentioned previously, which are important in themselves, there are two issues that are not so much related to the concept as to the 
context. The first has to do with the possible leap beyond the walls of the school institution or formal learning. In this sense, in the same way as with the prominence of narrative, we also find a consensus on the potential of transmedia in this regard $[15,17,23]$. Finally, the second contextual question that we pointed out has to do with the didactic concreteness of $\mathrm{TL}$, since it is not so much a question here of seeing how learning takes place in contexts of participatory culture (in the pedagogical sense), however interesting it may be, but rather of being able to apply it consciously in the design of $\mathrm{T}-\mathrm{L}$ experiences. In this sense, it is logical to recover storytelling as a didactic strategy. Although we said before that not all TL is storytelling (although it is story driven), it is unsurprising to deduce that taking learners to develop a story can be a way of approaching the learning situation from a didactic perspective, and all this with the aim of stimulating learners in multiple ways (doing, watching, listening, sharing, collaborating, reflecting, etc.) [13,20,21], offering them assorted channels that allow them the simultaneous or sequential use of different perspectives. In short, a didactic concreteness that is inspired by four principles: (1) a rich and varied narrative; (2) collaborative activities and challenges; (3) elements of gamification; and (4) connections between formal and informal learning.

Transmedia learning has been proposed as a wide range of educational options closely linked a priori with the principles of universal learning design [27,28], with the need to make the population digitally literate and to combat digital divides [29] (especially those of gender $[30,31])$. It is a very tempting opportunity to suggest meaningful learning at any educational level and with a wide range of possibilities. In fact, this wide range of possibilities, which allows the personalisation of learning and the design of motivating experiences linked to everyday life, links very well with the challenges of learning mathematics, and the need to combat, even 40 years later, the matemaphobia that Papert censured [32]. In this sense, the presence of technologies in the teaching of mathematics is neither new nor episodic: the tradition of including technological resources of all kinds in mathematical learning activities is already extensive, and there are many successful experiences in this sense $[33,34]$, in order to guarantee the development of the mathematical skills that students require to be able to progress in the rest of their learning and also in their growth as citizens [35]. The impact of the use of digital educational resources in the learning of mathematics, even in the earliest educational stages, has also been extensively demonstrated [36]. However, in many cases, they are experiences that remain localised in the subject and do not necessarily seek relationships with the rest of learning, as transmedia learning does, in a promising way [33]. Therefore, it is important to ask ourselves what are the transmedia learning experiences related to mathematics in order to analyse what knowledge they have contributed and to know from practice what their potentialities are.

Finally, we face the third vertex of this triangle: sustainability. The widespread use of technologies in education is not exempt from ethical questions [37,38], and one of these burning issues, increasingly, has to do with the environmental concerns that may arise from the consumption of digital goods and services and their impact on the environment (raw materials, resources, energy and technological waste) [39-41]. It is precisely in this context that it is appropriate to consider whether some potential characteristics of transmedia learning (flexibility in the use of resources, personalisation and low-tech profile) can make it a more sustainable bet and whether this greater sustainability of the didactic proposals of transmedia learning goes hand in hand with a clear and explicit vocation for education for sustainability.

\section{Materials and Methods}

In this context, the aim of this scoping literature review is to address how the possibilities of TL are being put into practice in the field of mathematics and how they deal with the different issues related to sustainability (from the ethical perspective and also as a didactic goal). The aim is to provide an overview of TL and mathematics, focusing mainly on how they apply the concept of TL and the related environmental issues. Therefore, three research questions (RQs) are formulated for this study: 
- RQ1. How Is TL applied in the didactics of mathematics?

- $\quad \mathrm{RQ2}$. Is TL a real opportunity for sustainable education based on the practical experiences analysed?

- RQ3. Is TL a sustainable option from the point of view of technological use?

In order to locate and analyse the most significant documents in relation to the research questions, the scoping review (SR) method has been used. An SR is an approach to the literature that is made with the intention of providing an overview of a subject under study with the intention of answering a general and panoramic research question [42]. Scoping reviews are extensive literature reviews that address broad research questions; therefore, they are primarily oriented towards exploring the available published knowledge and aim to provide a first map of the literature (as well as sizing up its dimensions and potential scope in a specific area). In our case, since this is an emerging area of knowledge (research on the educational possibilities of transmedia is incipient in general terms, and even more so in the field of mathematics), the aim of this review is to provide this general overview of the use of transmedia in mathematics education (general overview) with a specific look at sustainability.

For carrying out an optimal, ethical and traceable search, the criteria defined in the PRISMA statement [43] of inclusion and exclusion, relevance, validity of the studies, elimination of duplicates and application of Boolean operators were taken into account.

The documents under study respond to the search for the keywords ("transmedia learning" AND mathematics) in Spanish and English without any kind of time frame (the youth of the concept, with less than a decade, did not make it necessary). This search was carried out in the two main international multidisciplinary databases, Web of Science and Scopus, in the specific international database for education Educational Resources Information Center (ERIC) and, finally, also in Dialnet, one of the most prestigious Hispanic scientific repositories. Despite the difficulties of using it efficiently, Google Scholar was also used in this phase (in general, we refer here to the limitations of advanced search; for example, it is not possible to discard documents that have not gone through a peer-review process, nor to export lists to manage them more efficiently outside the browser).

To be included in the review, the main inclusion criteria is that the documents had to focus specifically on transmedia mathematics teaching-learning (T-L) processes, with no specific focus of interest as far as the educational stage is concerned, but rather the aim was to understand the uses of transmedia learning and their practical issues within the field of didactics of mathematics. The distinction between formal, non-formal and informal education has not been raised either. However, most of the documents obtained belong to the first group. As far as the exclusion criteria are concerned, it should be noted that taking into account the number of articles obtained in the searches and the fact that they were all relatively topical, it was decided not to apply any time filter. No type of discarding by language was carried out, given that all the articles that met the subject criterion were written in English.

As to the flow detailing the phases followed in the documentation process, which is characteristic of this type of literature review, in the first phase, the search was carried out on the basis of the descriptors indicated above, and a total of 42 documents were obtained. After detailed filtering (coherence with the topic of the research, peer-reviewed documents and clear reference to transmedia learning and mathematics), a final sample of 14 documents was obtained. As far as the number of articles analysed is concerned, it is considered to be an adequate number for a scoping review (which attempts to provide an overview of a novel or emerging object of study, especially in areas of research where a background of scientific literature is still being built up). Moreover, it should be noted that this is a specific topic and that it is difficult to find documents that combine transmedia teaching and mathematics. In this respect, it is important to underline that before deciding on the search formula and the databases used, several tentative tests were carried out, which yielded a smaller number of results, and the final applied sequence was the most productive one. 


\subsection{Sample}

The 14 documents submitted corresponded to different typologies: scientific articles (six), conference proceedings (four) and reports (four) and were produced between 2012 to 2020. The involved 14 texts can be found in the references list [44-56].

\subsection{Data Analysis Procedure}

Once retrieved all the final documents selected, they were added to an NVIVO 11 project (with a copy licenced by the Universitat de Girona) in order to conduct there a thematic analysis strategy $[43,57]$. As an initial step, data familiarisation was applied by reading and re-reading those articles and highlighting early ideas/perceptions related to the use of transmedia in the didactics of mathematics and sustainability. As a second step, the documents were coded to identify their contribution to a theme following the hints of the first stage. Starting themes were reviewed and redefined until the final themes were decided (underpinnings and common understanding of transmedia; key elements of transmedia and transmedia literacy; transmedia strategies applied to teach mathematics; prevailing didactic goals; resources and materials used; research findings, limitations and opportunities; explicit or implicit focus on sustainable education; technologies used/provided). Due to the similarities of the analysed texts, similar themes were found. In the following section, Table 1 synthesises the main of every document.

Table 1. Documents characteristics.

\begin{tabular}{cccccc}
\hline First Author & Year & Document Type & Research & Educational Context/Level & Geo. Context \\
\hline Alvarez & 2013 & Paper & Yes & Primary Education & Sweeden \\
De Jesús & 2020 & Conf. Proceed. & No & Higher education/STEM & Brazil \\
Johnson & 2016 & Paper & No & Preprimary Education & US \\
Llorente & 2015 & Conf. Proceed. & Yes & Preprimary Education & US \\
McCarthy & 2018 & Paper & Yes & Preprimary Education & US \\
McCarthy & 2013 & Conf. Proceed. & Yes & Preprimary Education & US \\
McCarthy & 2012 & Report & No & Preprimary Education & US \\
Pasnik & 2012 & Report & No & Preprimary Education & US \\
Pasnik & 2013 & Report & No & Preprimary Education & US \\
Paulsen & 2014 & Paper & Yes & Preprimary Education & US \\
Roberts & 2016 & Paper & Innovation & Preprimary Education & US \\
Rosenfeld & 2019 & Paper & Yes & Preprimary Education & US \\
Silander & 2016 & Conf. Proceed. & Yes & Preprimary Education & US \\
Stansell & 2016 & Theor. Paper & No & Secondary education/STEM & - \\
\hline
\end{tabular}

\section{Results}

\subsection{Metanalytical Synthesis}

The following Table 1 tries to synthesise the main metanalytical information of every document. All texts coming from the US and focusing on preprimary education belong to the same umbrella: applications, conceptualisations and experiences within the PBS Kids Ready to Learn Initiative [58].

For those texts with a research approach, Table 2 details how they have applied it. 
Table 2. Research approach.

\begin{tabular}{|c|c|c|c|c|c|}
\hline First Author & Year & Methodology & Instruments & Sample & Main Findings \\
\hline Alvarez & 2014 & Mixed & $\begin{array}{l}\text { Pre/post-test } \\
\text { Survey } \\
\text { ObservationInterviews }\end{array}$ & $\begin{array}{l}12 \text { students } \\
2 \text { teachers }\end{array}$ & $\begin{array}{l}\text { Collboard (a transmedia project } \\
\text { design) can foster the development } \\
\text { of Jenkin's three pillars: collective } \\
\text { intelligence, transmedia navigation } \\
\text { and distributed cognition }\end{array}$ \\
\hline Llorente & 2015 & $\begin{array}{l}\text { Randomised } \\
\text { controlled trial }\end{array}$ & Pre/post-test & $\begin{array}{c}+/-850 \text { children } \\
157 \text { teachers }\end{array}$ & $\begin{array}{l}\text { Children learn significantly more } \\
\text { Math and teachers express more } \\
\text { comfort and confidence }\end{array}$ \\
\hline McCarthy & 2018 & 2 case studies & $\begin{array}{l}\text { Mathematics } \\
\text { assessments } \\
\text { Observations } \\
\text { Interviews }\end{array}$ & $\begin{array}{l}68 \text { 3-5 yo. children } \\
\text { (and their families } \\
\text { and teachers) }\end{array}$ & $\begin{array}{l}\text { Improvement of learning outcomes } \\
\text { and attitudes, better children's } \\
\text { motivation and families' } \\
\text { implication }\end{array}$ \\
\hline McCarthy & 2013 & $\begin{array}{c}\text { Quasi- } \\
\text { experimental }\end{array}$ & $\begin{array}{l}\text { TEMA } \\
\text { Math. skills } \\
\text { Surveys } \\
\text { Digital logs }\end{array}$ & $\begin{array}{l}904 \text { yo. children } \\
\text { and their parents }\end{array}$ & $\begin{array}{l}\text { Improvement of knowledge, skills } \\
\text { and learning outcomes and parents' } \\
\text { awareness of their children's } \\
\text { learning }\end{array}$ \\
\hline Paulsen & 2014 & $\begin{array}{c}\text { Educational } \\
\text { evaluation }\end{array}$ & Pre/post-test & $\begin{array}{l}97 \text { families } \\
115 \text { children }\end{array}$ & $\begin{array}{l}\text { Significant improvement in } \\
\text { children's science knowledge } \\
\text { Significant improvement in } \\
\text { parental attitudes towards children } \\
\text { schooling }\end{array}$ \\
\hline Roberts & 2016 & Development & Learning analytics & $\begin{array}{l}\text { Algorithm } \\
\text { prototype } \\
\text { and } 10 \text { parents }\end{array}$ & $\begin{array}{l}\text { Providing detailed information to } \\
\text { parents is welcomed by them and } \\
\text { increases their interest in their } \\
\text { children's learning. }\end{array}$ \\
\hline Rosenfeld & 2019 & Mixed methods & $\begin{array}{l}\text { Tests } \\
\text { Observation } \\
\text { Reports }\end{array}$ & $\begin{array}{l}966 \text { children } \\
137 \text { teachers } \\
86 \text { preschool } \\
\text { classrooms }\end{array}$ & $\begin{array}{l}\text { Better mathematical knowledge for } \\
\text { students; better teachers' beliefs on } \\
\text { their own knowledge (also on the } \\
\text { benefits of using technologies) }\end{array}$ \\
\hline Silander & 2016 & $\begin{array}{l}\text { Randomised } \\
\text { controlled trial }\end{array}$ & Pre/post-test & $\begin{array}{l}1974-5 \text { yo. children } \\
14 \text { preschools }\end{array}$ & $\begin{array}{c}\text { General improvements in math. } \\
\text { Knowledge (but partial) } \\
\text { Better families' implication and } \\
\text { engagement }\end{array}$ \\
\hline
\end{tabular}

\subsection{RQ1. How Is TL Applied in the Didactics of Mathematics?}

From the documents analysed, we can say that transmedia learning is applied, in general terms, in a very simple didactic way in the experiences we found; in part, this is undoubtedly so because the educational level of texts analysed refers to primary education or even to the last years of infant education. Therefore, if we said that one of the most relevant elements of transmedia was the transition from the consumption of media resources to production, this is not something that we generally find in transmedia learning in mathematics. On the contrary, the concept of transmedia applies more to a vision of sequential change of audiovisual media (multimedia) and an express desire to jump the boundaries of the classroom school with different purposes. Thus, for example, in most of the experiences, we find is a combination (or alternation) of educational resources in different media (videos, games, readings, digital or hands-on activities) that revolve around the interaction between peers in the classroom and that, above all, aim to continue learning beyond the classroom hours [4,46-50]. Unlike more mature applications of transmedia learning (especially in higher education), there is not necessarily a narrative to develop, nor a personal process of elaboration of the learning resources, nor, therefore, they put the focus on the possibility for the learner to personalise and decide his or her own learning resource. Only in the experiences with older participants (middle or high school students), the spectrum is opened up, the didactics of mathematics in the most precise sense is skipped, and the TL is approached from a STEM perspective; it is at that moment when the remaining elements of the TL appear: storytelling at the service of research processes [45,56], as well as 
active methodologies that start from real-world phenomena and that pose real cases from which the learning experiences (here personal, creation-oriented and freely transmedia) are triggered [47].

Therefore, although their authors or teachers consider them to be transmedia learning experiences (precisely because of Jenkins' notion linked to transmedia navigation or transmedia storytelling, which is developed by jumping from medium to medium), they seem to us to be proposals closer to the flipped classroom model (because to a large extent some of the multimedia resources used are aimed at presenting contents of a more conceptual nature out of the classroom), and also proposals that, with the help of technological resources, aim to make up for the limitations of space and time of the ordinary school $[46,53]$. In all of them, however, this idea is relevant in the service of social development objectives, especially in disadvantaged contexts: raising projects such as PBS Kids [20,46-50] stems from an express will link the families that have more socioeconomic difficulties to accompany children's learning (in subjects such as mathematics so transcendent, due to their instrumental nature), and to a large extent, that much more ironclad guideline here than in other TL approaches responds to the will to facilitate the involvement of families and, with this, to improve the learning outcomes of the children to whom these learning designs are addressed.

This question leads us to consider what the affordances these texts recognise in TL, especially from the reflections on practice. Thus, for example, this social vision of transmedia is highlighted, which can contribute to narrowing gaps of different kinds (mathematical gaps but also digital ones; social and educational gaps in short) [46]. This, in turn, conditions many of the other affordances of TL that can be considered at the same time common characteristics of the experiences analysed (or, if you will, premises that teachers strive to seek with them): the widest possible accessibility for the entire educational population and increased engagement, both of students and their families [50-52,55].

Finally, the experiences analysed not only show theoretical approaches or assumptions but also provide some research evidence from the analysis of practice. Thus, for example, TL allows improving the learning of mathematics [53,55] and scientific knowledge [26]. McCarthy's different reflections also point to improvements in the learning outcomes of the participants, not only related to mathematical knowledge but also to all the other transversal competencies that end up being mobilised, such as digital competency [18]. If most of the conclusions reached from practice are resounding, it can be especially regarding the perception of how the attitudes towards learning of both students and families improve $[26,46,53,55]$, in response to the expectation that was conceived at the beginning of how to approach learning experiences in transmedia mode can promote the engagement of the entire educational community.

\subsection{RQ2. Is Transmedia Learning a Real Opportunity for Sustainable Education Based on the Practical Experiences Analysed?}

Since 2015, when the assembly for the approval of the "post-2015 development agenda" was held, in which the 17 goals for sustainable development-the well-known Sustainable Development Goals (SDG)—were established, awareness of sustainability has become increasingly popular. Those goals comprise the concept of sustainability from five major axes. These are: (1) the people, for whom their well-being must be ensured at all levels; (2) the planet, which must be cared for by avoiding its degradation by, among other things, carrying out unsustainable consumption; (3) the vital prosperity of all the inhabitants of the planet; (4) peace in societies at the global level; and (5) partnerships at the global level to achieve the well-being of all citizens and the achievement of the SDGs [58]. From this perspective, sustainability can be seen as an amalgam of elements that are essential for quality global development and involve actions at both the environmental and social levels.

If the articles included in the scoping review process are analysed from a global point of view, it can be considered that 10 of the 14 articles work on sustainability from the more social perspective of sustainability (and not explicitly; or at least not as a declared didactic objective in itself). Specifically, they focus on the development of SDG number four on qual- 
ity education. A clear example of this is the papers by McCarthy et al. [48,49], Johnson [46], Pasnik and Llorente [51,56], Roberts et al. [53], Rosenfeld et al. [54], Silander et al. [55] and Llorente et al. [50], which address the process of mathematics T-L through the transmedia narrative with the intention of providing support and avoiding the risk of academic failure for children from low-income families. Similarly, Paulsen and Andrews [51], Stansell et al. [56], Alvarez et al. [44] and De Jesus et al. [45] integrate transmedia storytelling with the intention of improving the mathematics T-L process. Consequently, $71.43 \%$ of the analysed documents do not only focus on improving the T-L process but go further and propose interests related to supporting families that may present more economic difficulties.

However, there is no doubt that, to a large extent, we are approaching sustainability from the didactic perspective in a very broad way, and this is due to the lack of explicit recognition of this concept from the environmental point of view. There is no declared intention for educational proposals to work on the values of sustainable education in general, nor on the values of environmental protection in particular. Therefore, if the analysis is based on the concept of sustainability in the use of technology in education proposed by other authors, it can only be considered that two of the articles work directly with content related to the promotion of an eco-technological culture, creating systems to improve the quality of life. Specifically, those are Stansell et al. [56] and De Jesus et al. [45] articles that focus on mathematics related to agriculture and programming with this explicit perspective of addressing didactic objectives linked to sustainability.

\subsection{RQ3. Is Transmedia Learning a Sustainable Option from the Point of View of Technological Use?}

Finally, if we study sustainability from its most environmental aspect and analyse consumption and waste management, it is difficult to determine which of the authors make a strictly responsible use or not. This is because it does not appear explicitly in the documents (to some extent, this lack of information on the subject can be taken as a clue to the absence of reflection on sustainability when programming the use of digital educational resources). In this sense, we take up the ideas of Elshof [59] or Baena-Morales et al. [41] or even from a perspective that links sustainability with scalability [60]; there, to the extent that the reflection on how technologies are used is not explicit, we should consider which elements can be considered closer to the concept of sustainable technological consumption (again, we take up here the perspective of scalability). For example, in the case of the Roberts et al. study [53], many of the families consider that they want to access T-L resources from their own mobile devices, and the experiences are designed in this sense. Something similar happens in the study by McCarthy et al. [48], where the content is provided in video format, but families use their own devices to play it. These are two clear examples of how such practices do not have to involve an increase in technological consumption; it is simply necessary to generate the material in formats that take into account what devices are available to the participants in the research or T-L process, which in turn links to the principles of universal design for learning.

However, it is noteworthy that on the opposite side is the article by Roberts et al. [53], who makes an unsustainable consumption by providing the teachers who participate in the study with interactive whiteboards, laptops specially designed for preschool use and broadband internet, while the students involved in the experience also receive their corresponding technological devices. Considering that a total of 137 teachers and almost one thousand students participated in the study and that all of them received their own device (computer and digital whiteboard for each teacher, computer for each student), we are talking about too many additional devices for the experience to be considered green.

Finally, in the middle of these two extremes, as we said at the beginning of the section, we have a considerable absence of reference to how ethical issues linked to sustainability are addressed in the proposed technology-mediated educational practices. Undoubtedly, one element that may have to do with this silence is the usual limitations of space in scientific discourse, which lead to focus on what we want to tell, neglecting the non-central elements. 
However, the fact that reflection on sustainability is systematically among those details that are ignored does not fail to reveal a level of awareness in techno-educational practice.

\section{Discussion and Conclusions}

At this point, if we go back to the first research question, in which we ask ourselves what the most common approach to transmedia learning is within the didactics of mathematics, based on what we have found, we see important elements in relation to the beneficial use of different media, at different times, taking advantage of the potential of each of them. We also detected that most of the experiences linked to the PBS Kids project [20] are born with a clear vision of using technologies with a low technological profile (in consumption), such as video with a clear vocation of universality and accessibility, at the service of social cohesion objectives in unfavourable socioeconomic contexts. As a consequence of the technological development mentioned in the introduction, the authors propose to take advantage of the potential of the different media at their disposal: different resources are offered for different moments and in different situations [8]. These are very interesting elements from the point of view of both universal design and the scalability of digital educational experiences [26,55]. However, one of the most potentially transcendent elements of TL, such as the leap from consumption to production and the development of transmedia narratives, only appears in experiences with older students and within the STEM field [45,56]. In fact, it is striking the absence of explicit references to the importance of transmedia storytelling (or being more precise, to a narrative): students do not unfold a story as a learning challenge but perform different learning activities in different media and different moments. This 'changing-media' sequence is what makes the authors consider them transmedia experiences, and this absence of narratives does not offer the students the possibility to produce their own materials, to become prosumers (not only costumers): in part, students do not jump into production precisely because they do not have to develop the narrative [7-10]. Finally, the results of the research carried out in these contexts are undoubtedly promising (but still to be generalised in a more systematic way): improvements in learning outcomes and in the engagement of both students and families $[46,55]$. However, from both a mathematical didactic perspective and in terms of universal design and personalisation of learning, there is still a long way to go $[9,16]$.

Furthermore, if we focus on research questions two and three and recapitulate all the information presented in relation to the sustainability of transmedia approaches to learning mathematics, three main ideas can be extracted. First, transmedia documents on mathematics T-L do not explicitly address sustainability, and only a minority of them deal with content directly related to the conception of sustainability in the use of educational technology [60]. Secondly, educational researchers and practitioners tend to opt for sustainable choices in terms of the use of resources, although this cannot always be said to be a goal, as there is little or no reflection on this issue. As already mentioned, in many of the articles analysed, it is made explicit that use is made of materials that were already available beforehand and, therefore, resources are not used that have been prepared or acquired ad hoc. In addition, the resources are created with the possibility of accessing them from different devices in mind [48], which provides the option of accessing them independently of the type of resources available to both the families and the centres (and does not force an unplanned technological consumption for other purposes). Thirdly, it can be considered that if this analysis is made from a social perspective of sustainability, most educational practices included in the documents analysed are aligned with SDG 4 of the United Nations [61], referring to quality education, given that they work with the intention of providing equal training opportunities to groups with a certain degree of risk of social exclusion.

Finally, if we focus on the more quantitative results of the scoping review, it is noteworthy that most of the documents analysed focus on the geographical context of the United States (11 out of 14 documents) and, more specifically, on the primary education stage (12 out of 14 documents). Furthermore, it is relevant to underline that the oldest document 
included in the review is from 2012, and the most current is from 2020. All this, together with the information presented above, shows, on the one hand, that the subject of TL in the teaching-learning processes of mathematics is quite modern. However, on the other hand, taking into account the number of articles resulting from the selection process and the geographical and political context of some of them, it is clear that there is still a long way to go to exploit the potential of TL in the field of mathematics teaching.

Author Contributions: Conceptualization, A.S.-C. and J.G.-M.; methodology, A.S.-C.; formal analysis, A.S.-C. and J.G.-M.; resources, J.G.-M.; data curation, A.S.-C.; writing-original draft preparation, A.S.-C. and J.G.-M.; writing-review and editing, J.G.-M. All authors have read and agreed to the published version of the manuscript.

Funding: This research received no external funding.

Institutional Review Board Statement: Not applicable.

Informed Consent Statement: Not applicable.

Data Availability Statement: Not applicable. This study did not report any data.

Conflicts of Interest: The authors declare no conflict of interest.

\section{References}

1. Gee, J.P. New Digital Media and Learning as an Emerging Area and "Worked Examples" as One Way Forward; The MIT Press: Cambridge, MA, USA, 2009.

2. Ito, M.; Gutiérrez, K.; Livingstone, S.; Penuel, B.; Rhodes, J.; Salen, K.; Schor, J.; Sefton-Green, J.; Watkins, S.C. Connected Learning: An Agenda for Research and Design; Digital Media and Learning Research Hub: Irvine, CA, USA, 2013.

3. Jenkins, H. Convergence Culture. Where Old and New Media Collide; Nwe York University Press: New York, NY, USA, 2006.

4. Jenkins, H.; Clinton, K.; Purushotma, R.; Robison, A.J.; Weigel, M. Confronting the Challenges of Participatory Culture: Media Education for the 21st Century; The MacArthur Foundation: Chicago, IL, USA, 2009. [CrossRef]

5. Scolari, C.A. Adolescents, Media and Collaborative Cultures. Harnessing the Transmedia Competencies of Young People in the Classroom; Universitat Pompeu Fabra: Barcelona, Spain, 2018.

6. Scolari, C.A. The hour of the prosumer. Cactus 2015, 4, 24-26.

7. González-Martínez, J.; Esteban-Guitart, M.; Rostan-Sanchez, C.; Serrat-Sellabona, E.; Estebanell-Minguell, M. What's up with transmedia and education? A literature review. Digit. Educ. Rev. 2019, 36, 207-222. [CrossRef]

8. Dickinson-Delaporte, S.; Gunness, A.; McNair, H. Engaging Higher Education Learners with Transmedia Play. J. Mark. Educ. 2020, 42, 123-133. [CrossRef]

9. Fleming, L. Expanding Learning Opportunities with Transmedia Practices: Inanimate Alice as an Exemplar. J. Media Lit. Educ. 2013, 52, 370-377. Available online: https: / / digitalcommons.uri.edu/cgi/viewcontent.cgi?article=1124\&context=jmle (accessed on 31 August 2021).

10. Pereira, M.A.G.; Pedro, L.F.M.M.G. Ambientes colaborativos transmedia para a promoção da autonomia e motivação dos estudantes. In Proceedings of the 15th Iberian Conference on Information Systems and Technologies (CISTI), Seville, Spain, 24-27 June 2020; pp. 1-6. [CrossRef]

11. Amador, J. Transmedia learning in the age of interactive cultural convergence. Educ. City 2013, 25, 11-24.

12. Davis, S. Drama and arts-based professional learning: Exploring face-to-face, online and transmedia models. Teach. Educ. 2017, 28, 333-348. [CrossRef]

13. Wiklund-Engblom, A.; Hiltunen, K.; Hartvik, J.; Porko-Hudd, M. Transmedia storybuilding in Sloyd. In Proceedings of the IADIS International Conference Mobile Learning, Lisbon, Portugal, 14-16 March 2013; pp. 199-203. [CrossRef]

14. Rodrigues, P.; Bidarra, J. Expanding the Mosaic of Transmedia Learning Experiences: Application of a Transmedia Storyworld in ESL Formal Learning Environments. In Proceedings of the 9th International Conference on Digital and Interactive Arts, Braga, Portugal, 23-25 November 2019; pp. 1-11. [CrossRef]

15. Chung, G.K.W.K. Toward the Relational Management of Educational Measurement Data. Teach. Coll. Rec. 2014, 116, 1-16. Available online: https://www.ets.org/Media/Research/pdf/chung_toward_relational_management_educational_measurement.pdf (accessed on 31 August 2021). [CrossRef]

16. Raybourn, E.M. A new paradigm for serious games: Transmedia learning for more effective training and education. J. Comput. Sci. 2014, 5, 471-481. [CrossRef]

17. Barreneche, C.; Polo Rojas, N.D.; Menéndez-Echavarría, A.L. Alfabetismos Transmedia en Colombia: Estrategias de aprendizaje informal en jóvenes gamers en contextos de precariedad. Chasqui. Rev. Latinoam. Comun. 2018, 171-189. [CrossRef]

18. Ellis, G.W.; Huff, I.; Rudnitsky, A.; McGinnis-Cavanaugh, B.; Ellis, S.K. Engaging children in design thinking through transmedia narrative (RTP). In Proceedings of the 2018 ASEE Annual Conference \& Exposition, Salt Lake City, UT, USA, $24-27$ June 2018. [CrossRef] 
19. Gutu, M. A new perspective on learning: Flipped classroom and transmedia learning. In E-Learning: Unlocking the Gate to Education arround the Globe, Proceedings of the 14th Conference Reader 2019, Prague, Czech Republic, 20-21 June 2019; Centre for Higher Education Studies: Prague, Czech Republic, 2019; pp. 240-245.

20. McCarthy, B.; Li, L.; Tiu, M.; Atienza, S.; Sexton, U. Learning with PBS KIDS A Study of Family Engagement and Early Mathematics Achievement); WestEd: San Francisco, CA, USA, 2015. Available online: https:/ / www.wested.org/resources/learning-with-pbskids/ (accessed on 31 August 2021).

21. Valdés Sánchez, V.; Gutiérrez Esteban, P.; Capilla Garrido, E. Diseño de materiales curriculares en Educación infantil: De la convergencia de medios a la educación transmedia. In Tecnología, Innovación e Investigación en Los Procesos de Enseñanza-Aprendizaje; Roig-Vila, R., Ed.; Octaedro: Barcelona, Spain, 2016; pp. 1424-1431.

22. Campalans, C. Transmedia teaching/learning: An experience. Razón y Palabra 2015, 16, 39-55. [CrossRef]

23. Rodrigues, P.; Bidarra, J. Design of a Transmedia Project targeted to Language Learning. In Proceedings of the 7th International Conference on Digital Arts, Óbidos, Portugal, 18-20 March 2015; pp. 1-7.

24. Raybourn, E.M.; Kunz, M.; Fritz, D.; Urias, V. A zero-entry cyber range environment for future learning ecosystems. In Cyber-Physical Systems Security; Koç, Ç.K., Ed.; Springer: Cham, Switzerland, 2018; pp. 93-109.

25. Raybourn, E.M. Toward culturally-aware, next generation learning ecosystems. Adv. Intell. Syst. Comput. 2017, 480, 173-181. [CrossRef]

26. Paulsen, C.A.; Andrews, J.R. The Effectiveness of Placing Temporal Constraints on a Transmedia STEM Learning Experience for Young Children. E-Learn. Digit. Media 2014, 11, 204-213. [CrossRef]

27. Alba Pastor, C. Universal Design for Learning. Education for All and Inclusive Teaching Practices; Ediciones Morata: Madrid, Spain, 2016.

28. Castro, R.; Rodríguez, F. Universal Design for Learning and Co-Teaching; Ediciones Universidad Santo Tomás: Santiago, Chile, 2017.

29. van Dijk, J.A. Digital Divide: Impact of Access. In The International Encyclopedia of Media Effects; Rössler, P., Hoffner, C.A., van Zoonen, L., Eds.; John Wiley \& Sons Inc: Hoboken, NJ, USA, 2017; pp. 1-11.

30. Barragán, R.B.; Ruiz-Pinto, E. Gender gap and digital inclusion. El potencial de las redes sociales en educación. Profesorado. Rev. Currículum Form. Profr. 2013, 17, 309-323.

31. Clark, C.; Gorski, P. Multicultural Education and the Digital Divide: Focus on Disability. Multicult. Perspect. 2002, 4, 28-36. [CrossRef]

32. Papert, S. Mindstorms: Children, Computers, And Powerful Ideas; Basic Books: New York, NY, USA, 1980.

33. Cheung, A.C.K.; Slavin, R.E. The effectiveness of educational technology applications for enhancing mathematics achievement in K-12 classrooms: A meta-analysis. Educ. Res. Rev. 2013, 9, 88-113. [CrossRef]

34. Young, J. Technology-enhanced mathematics instruction: A second-order meta-analysis of 30 years of research. Educ. Res. Rev. 2017, 22, 19-33. [CrossRef]

35. Murphy, D. A Literature Review: The Effect of Implementing Technology in a High School Mathematics Classroom. Int. J. Res. Educ. Sci. 2016, 2, 295-299. [CrossRef]

36. Verbruggen, S.; Depaepe, F.; Torbeyns, J. Effectiveness of educational technology in early mathematics education: A systematic literature review. Int. J. Child. -Comput. Interact. 2021, 27, 100220. [CrossRef]

37. Olcott, D.; Farran, X.C.; Echenique, E.E.G.; Martínez, J.G. Ethics and Education in the Digital Age: Global Perspectives and Strategies for Local Transformation in Catalonia. RUSC. Univ. Knowl. Soc. J. 2015, 12, 59. [CrossRef]

38. Carrera Farran, F.X.; González Martínez, J.; Coiduras Rodríguez, J.L. Ética e investigación en Tecnología Educativa: Necesidades, oportunidades y retos. Rev. Interuniv. Investig. Tecnol. Educ. 2016, 34-43. [CrossRef]

39. Abad-Segura, E.; González-Zamar, M.-D.; Rosa, A.L.-D.L.; Cevallos, M.B.M. Sustainability of educational technologies: An approach to augmented reality research. Sustainability 2020, 12, 4091. [CrossRef]

40. Anderson, T.; Rivera-Vargas, P. A critical look at educational technology from a distance education perspective. Digit. Educ. Rev. 2020, 208-229. [CrossRef]

41. Baena-Morales, S.; Martinez-Roig, R.; Hernádez-Amorós, M. Sustainability and educational technology-A description of the teaching self-concept. Sustainability 2020, 12, 10309. [CrossRef]

42. Scharew, H.; Macluso, M. Methods for Research Evidence Synthesis: The Scoping Review Approach. J. Hosp. Med. 2019, 14, 416-418. [CrossRef]

43. Urrútia, G.; Bonfill, X. PRISMA statement: A proposal to improve the publication of systematic reviews and meta-analyses. Med. Clin. 2010, 135, 507-511. [CrossRef]

44. Alvarez, C.; Salavati, S.; Nussbaum, M.; Milrad, M. Collboard: Fostering new media literacies in the classroom through collaborative problem solving supported by digital pens and interactive whiteboards. Comput. Educ. 2013, 63, 368-379. [CrossRef]

45. Jesus, M.A.D.; Estrela, V.V.; Mamani WD, H.; Razmjooy, N.; Plaza, P.; Peixoto, A. Using transmedia approaches in STEM. In Proceedings of the IEEE Global Engineering Education Conference, EDUCON, Porto, Portugal, 27-30 April 2020; pp. $1013-1016$. [CrossRef]

46. Johnson, P.; Steven, D.; Lovitts, B.E.; Lowenstein, D.; Rodriguez, J. Leveraging transmedia content to reach and support underserved children. J. Child. Media 2016, 10, 267-275. [CrossRef] 
47. Llorente, C.; Pasnik, S.; Moorthy, S.; Hupert, N.; Rosenfeld, D.; Gerard, S. Preschool Teachers Can Use a PBS KIDS Transmedia Curriculum Supplement to Support Young Children's Mathematics Learning: Results of a Randomized Controlled Trial. In A Report to the CPB-PBS Ready to Learn Initiative. In Proceedings of the Society for Research on Educational Effectiveness Spring 2015 Conference, Washington, DC, USA, 4-8 March 2015; Available online: https:// files.eric.ed.gov/fulltext/ED562360.pdf (accessed on 31 August 2021).

48. McCarthy, B.; Li, L.; Tiu, M. PBS KIDS Mathematics Transmedia Suites in Preschool Homes. A Report to the CPB-PBS Ready To Learn Initiative (Issue September). 2012. Available online: https://www.wested.org/resources/pbs-kids-mathematicstransmedia-suites-in-preschool-homes-a-report-to-the-cpb-pbs-ready-to-learn-initiative/\# (accessed on 29 November 2021).

49. McCarthy, B.; Li, L.; Tiu, M.; Atienza, S. PBS KIDS mathematics transmedia suites in preschool homes. In Proceedings of the 12th International Conference on Interaction Design and Children, New York, NY, USA, 24-27 June 2013; pp. 128-136. [CrossRef]

50. McCarthy, E.; Tiu, M.; Li, L. Learning Math with Curious George and the Odd Squad: Transmedia in the Classroom. Technol. Knowl. Learn. 2018, 23, 223-246. [CrossRef]

51. Pasnik, S.; Llorente, C. 2012 Preschool Pilot Study of PBS KIDS Transmedia Mathematics Content 2012 (Issue September). EDC/SRI International. 2012. Available online: http://cct.edc.org/publications/2012-preschool-pilot-study-pbs-kidstransmedia-mathematics-content (accessed on 29 November 2021).

52. Pasnik, S.; Llorente, C. Preschool Teachers Can Use a PBS KIDS Transmedia Curriculum Supplement to Support Young Children's Mathematics Learning: Results of a Randomized Controlled Trial; WestEd: San Francisco, CA, USA, 2012. Available online: https:/ /www.edc. org/preschool-teachers-can-use-pbs-kids-transmedia-curriculum-supplement-support-young-children\%E2\%80\%99s (accessed on 31 August 2021).

53. Roberts, J.D.; Chung GK, W.K.; Parks, C.B. Supporting children's progress through the PBS KIDS learning analytics platform. Journal of Children and Media 2016, 10, 257-266. [CrossRef]

54. Rosenfeld, D.; Dominguez, X.; Llorente, C.; Pasnik, S.; Moorthy, S.; Hupert, N.; Gerard, S.; Vidiksis, R. A curriculum supplement that integrates transmedia to promote early math learning: A randomized controlled trial of a PBS KIDS intervention. Early Child. Res. Q. 2019, 49, 241-253. [CrossRef]

55. Silander, M.; Moorthy, S.; Dominguez, X.; Hupert, N.; Pasnik, S.; Llorente, C. Using Digital Media at Home to Promote Young Children's Mathematics Learning: Results of a Randomized Controlled Trial. In Proceedings of the Society for Research on Educational Effectiveness Spring 2015 Conference, Washington, DC, USA, 4-8 March 2015. Available online: https:/ / eric.ed.gov / ?id=ED567485 (accessed on 31 August 2021).

56. Stansell, A.; Tyler-Wood, T.; Austin, S. The development of a transmedia STEM curriculum: Implications for mathematics education. J. Math. Educ. 2016, 9, 72-80.

57. Okoli, C.; Schabram, K. A Guide to Conducting a Systematic Literature Review of Information Systems Research. Work. Pap. Inf. Syst. 2010, 10, 1-51. [CrossRef]

58. United Nations. Report of the Secretary-General on the Work of the Organization; United Nations: New York, NY, USA, 2015. Available online: https://undocs.org/es/A/70/1 (accessed on 31 August 2021).

59. Elshof, L. Toward sustainable practices in technology education. Int. J. Technol. Des. Educ. 2009, 19, 133-147. [CrossRef]

60. Niederhauser, D.S.; Howard, S.; Voogt, J.; Agyei, D.D.; Laferriere, T.; Tondeur, J.; Cox, M.J. Sustainability and Scalability in Educational Technology Initiatives: Research-Informed Practice. Technol. Knowl. Learn. 2018, 23, 507-523. [CrossRef]

61. United Nations. Sustainable Development Goals 2020 Report; United Nations: New York, NY, USA, 2020. Available online: https: // unstats.un.org/sdgs/files/report/2018/TheSustainableDevelopmentGoalsReport2018-ES.pdf (accessed on 31 August 2021). 